\title{
EDITORIAL
}

\section{Cyclosporine: Is there a role in inflammatory bowel disease?}

\author{
RICHARD N. FEDORAK, MD
}

$\mathrm{T}$

HE IDIOPATHIC INFLAMMATORY BOWEL DISEASES (IBD) are a spectrum of disorders characterized by chronic inflammation of the gastrointestinal tract. Genetic (1-5), environmental (6), dietary (7) and infectious agents (7,8-15) have been implicated in the cause of IBD; however, much more evidence is required before any is considered proven. Because the exact etiology of IBD has thus far been difficult to establish many investigators consider that the basis of the disease lies in an endogenous immunological defect. Thirty years ago Broberger and Pearlmann (16) first demonstrated that IBD was associated with anti-epithelial cell antibodies in both blood and draining lymph nodes in patients with ulcerative colitis. Since then a large body of evidence has grown to support the immunologic hypothesis of IBD pathogenesis.

Prior to examining the concept that IBD is a consequence of an immunologic process it is important to review the function of the mucosal immune system in normal individuals. The gastrointestinal luminal environment contains numerous substances capable of activating the immune system. However, the fact that this does not occur can be attributed to the mucosal immune systems 'programmed' un-

Correspondence: Dr Richard N. Fedorak, Division of Gastroenterology, Department of Medicine, 519 Robert Newton Research Building, University of Alberta, Edmonton, Alberta, T6G 2C2 responsiveness. For example, during antigen-specific reactions, protein antigens entering the gastrointestinal tract via the oral route produce antigen-specific suppressor $T$ cells with negative effects on the immune system rather than helper $\mathrm{T}$ cells with their stimulatory effects (17-19). With antigen-nonspecific reactions the mucosal immune response is again influenced by antigen-nonspecific suppressor $\mathrm{T}$ cell mechanisms $(20,21)$. The one exception to mucosal unresponsiveness is that of per oral immunization evoking a positive $\operatorname{Ig} \mathrm{A}$ immune response, while at the same time causing a negative suppressor $T$ cell response. Because $\lg \mathrm{A}$ antibodies provide a 'scavenger' function to eliminate 'foreign' antigens which inadvertently gain entry via the mucosal surface, a positive $\lg \mathrm{A}$ response is, in the end, reducing the immune system response as a whole.

The earlier lesions of Crohn's disease, and likely ulcerative colitis, do not begin within the enterocyte but rather as an accumulation of plasma cells and lymphocytes adjacent to mucosal crypts (22). This is followed by an influx of macrophages and subsequent inflammatory processes within the lamina propria. Damage to the enterocyte is, therefore, a by-product of this underlying inflammatory process.

The mature inflammatory lesions in IBD contain a threefold enhancement in lymphocytes (both $T$ cells and B cells increased to a similar extent) compared to normal mucosa (23). The increased B cell population in IBD tends to be 
located in superficial areas of the mucosa and is composed of both nonimmunoglobulin and immunoglobulin producing $\mathrm{B}$ cells. Within the immunoglobulin producing population $\lg M$ and $\operatorname{IgG}$ predominate over $\operatorname{Ig} \mathrm{A}$ and $\lg E$ plasma cells, reversing the normal gastrointestinal mucosal $\operatorname{IgA}$ predominance $(24-27)$. The increased $T$ cell population in IBD is located in deeper regions of the mucosa and muscle layers and is composed of both T4 (helper) cells and T8 (suppressor) cells in the same 2:1 ratio as normal mucosa (28). In addition to the lymphocytes, increased numbers of inflammatory cells are also present in IBD (29). Neutrophils (particularly in ulcerative colitis), eosinophils and macrophages (particularly in Crohn's disease) and mast cells are localized to the submucosa where they release vasoactive amines which further alter vascular permeability and facilitate the influx of additional inflammatory elements into the IBD lesion $(29,30)$.

Not only are the $B$ and $T$ cell systems increased in number but also in immune functional activity. B cell activity can be demonstrated by an increased antibody response to the $\mathrm{B}$ cell mitogen lipopolysaccharide and the enterobacterial common antigen of Kunin, a bacterial cell wall constituent of many enterobacteria $(31,32)$. Increased suppressor $\mathrm{T}$ cell activity can be demonstrated by the fact that peripheral $\mathrm{T}$ cells obtained from patients with IBD produce migration inhibition factor when exposed to the enterobacterial common antigen of Kunin $(33,34)$. Ultimately, however, the T cell population from which the suppressor T cells originate is depleted or perhaps suppressed. At this point one sees reduced rather than increased suppressor $T$ cell activity and it is at this point that the immune defect of IBD becomes manifest.

These changes in $B$ and $T$ cell number and function may simply be due to mucosal inflammation and the consequent increase in exposure of the immune system to mucosal antigens. However, it is more likely to be a primary mucosal immunoregulatory defect; specifically, a fault in the 'programmed' unresponsiveness of the gastrointestinal mucosa.

\section{SEQUENCE OF EVENTS}

In summary, one can propose the following sequence of pathologic events leading to IBD. The gastrointestinal immune system becomes exposed to a mucosal antigen, perhaps even an antigen normally present within the lumen, ie, a bacterial constituent of normal flora. However, on this occasion the antigen does not evoke the typical antigen-specific suppressor $\mathrm{T}$ cell activity, ie, mucosal unresponsiveness, but, because of an antigen-specific immunoregulatory defect, it evokes helper $T$ cell activity and sets into play an ongoing immune response. This immune response as an epiphenomenon leads eventually to the development of self antigens and appearance of autoantibodies. Subsequently, in an attempt to down regulate the antigen-specific response, antigen-nonspecific suppressor $T$ cells appear. Initially these antigen-nonspecific suppressor $T$ cells may prevent disease progression; however, they are gradually depleted leaving the unregulated antigen-specific helper $\mathrm{T}$ cell activity to predominate. This unregulated antigen-specific immune response leads to the production of lymphokines which stimulate migration of inflammatory and cytolytic cells to the region. Through this process the microscopic and gross morphological changes of IBD are manifest.

Therapy for Crohn's disease has up to now consisted of corticosteroids, immunosuppressive agents and, to a lesser extent, 5-ASA and metronidazole $(35,36)$. Efficacy of therapy in acute disease, however, has for the most part been suboptimal, while a definite absence of therapy exists for preventing relapses. With the hypothesis that IBD may indeed be related to an immune regulatory dysfunction, potent immunosuppressive agents may be useful where other therapy has failed.

Cyclosporine $\mathrm{A}$ is a unique fungal metabolite which possesses potent specific immunosuppressive properties (37). Cyclosporine interferes with helper $\mathrm{T}$ cell activity by binding to specific membrane receptors, subsequently inhibiting cell growth and interleukin-2 lymphokine release. This depletion of interleukin-2 interferes with B cell and helper $T$ cell proliferation while allowing the expansion of the suppressor $\mathrm{T}$ cell population. In this way cyclosporine may return the immunoregulatory defect of the gastrointestinal immune response seen in IBD to the normal state of 'programmed' unresponsiveness.

\section{CLINICAL TRIALS}

Cyclosporine has now been used in treating over $100 \mathrm{pa}$ tients with Crohn's disease worldwide. Many of these are anecdotal experiences or open trials with small numbers of subjects (38-43). Often the cyclosporine was utilized only after conventional therapy failed. Nevertheless, in this difficult patient population the initial overall response rate while on cyclosporine was approximately $70 \%$ (44). Allison and Pounder $(40,41)$ in an open trial treated eight patients with uncomplicated Crohn's disease who were resistant to conventional therapy. All the patients were able to tolerate the mean cyclosporine dose rate of $8.2 \mathrm{mg} / \mathrm{kg} /$ day (range 2.5 to $10 \mathrm{mg} / \mathrm{kg} /$ day) for the six-week duration of the study. Seven of the eight patients responded to cyclosporine with symptomatic improvement, a fall in the Crohn's Disease Activity Index and return of the C-reactive protein concentration to normal. Nevertheless, all patients relapsed within the first week of stopping cyclosporine treatment.

Brynskov and colleagues (42), in an open multicentre study in Denmark, examined the use of cyclosporine over three months in 11 patients with therapy-resistant active Crohn's disease. One patient, unable to absorb the cyclosporine, was excluded from the study at two weeks. The remainder of the subjects tolerated a dose rate of 5 to 7.5 $\mathrm{mg} / \mathrm{kg} /$ day with minimal side effects. After three months of therapy, two of 11 patients (18\%) failed to respond. Eight of 11 patients $(72 \%)$ improved, however, only three of these eight patients $(38 \%)$ remained in remission once the cyclosporine was withdrawn. 
In this issue of The Canadian Journal of Gastroenterology Peltekian and colleagues (p5) examined the use of cyclosporine in 15 patients with active Crohn's disease refractory to conventional therapy. Similar to the earlier studies, cyclosporine doses were monitored to maintain serum trough levels of cyclosporine between 100 and 200 $\mathrm{ng} / \mathrm{mL}$. Nevertheless, five of 15 patients withdrew early from the study (three because of side effects; one because of poor absorption; one because of noncompliance). Although the trial was open and the study population small it is encouraging to see that four weeks after beginning cyclosporine, all 10 patients able to tolerate the drug demonstrated improvement as documented by a fall in the Crohn's Disease Activity Index, Simple Index of Crohn's Activity, and reduction in corticosteroid requirements. However, by 16 weeks of therapy only seven of these 10 patients remained improved and once the cyclosporine was stopped only three of them $(30 \%)$ remained in remission at $75 \pm 2$ weeks of follow-up.

These results of an early clinical response to cyclosporine therapy, followed by frequent and often rapid relapses once the cyclosporine is stopped, are similar to those of earlier trials with cyclosporine $(41,42)$. This contrasts, however, with the use of prednisone and 6-mercaptopurine where the mean onset of response is longer and the relapse rate following withdrawal is not as high as that seen with cyclosporine (45). It is interesting to note that, in the present study as well as in earlier reports, corticosteroids were aggressively tapere 4 or discontinued following the cyclosporine response. Perhaps a more liberal use of corticosteroids may

\section{REFERENCES}

1. Lewkonia RM, McConnell RB. Familial inflammatory bowel disease - heredity or environment?

Gut 1976;17:235-43.

2. Delpre G, Kadish U, Gazit E, Joshua H, Zamir R. HLA antigens in ulcerative colitis and Crohn's disease in Israel. Gastroenterology 1980;78:1452-7.

3. Eade OE, Moulton C, MacPherson BR, Andre-Ukena SS, Albertini RJ, Beeker WL. Discordant HLA haplotype segregation in familial Crohn's disease. Gastroenterology 1980;79:271-5.

4. Asakura H, Tsuchiya M, Aiso S. Association of the human lymphocyte-DR2 antigen with Japanese ulcerative colitis. Gastroenterology 1982;82:413-8.

5. Pena AS, Biemond I, Kuiper G, et al. HLA antigen distribution and HLA haplotype segregation in Crohn's disease. Tissue Antigens 1980;16:56-61.

6. Gilat T, Rozen P. Epidemiology of Crohn's disease and ulcerative colitis: Etiologic implications. Is J Med Sci 1979;15:305-8.

7. Kirsner JB, Shorter RG. Recent developments in "nonspecific" inflammatory bowel disease. N Engl J Med 1982;306:775-83.

8. Chiodini RJ, Van Kruiningen HJ, Merkal RS, Thayer WR Jr, Coutu JA. Characteristics of an unclassified Mycobacterium species isolated from patients with Crohn's disease. J Clin Microbiol 1984;20:966-71.

9. Cave DR, Mitchell DN, Brooke BN. Induction of granulomas in mice by Crohn's disease tissues. have altered the high relapse rate encountered when cyclosporine was withdrawn.

\section{SIDE EFFECTS}

Cyclosporine is known to predictably reduce glomerular filtration rate and cause mild hypertension, hypertrichosis, mild liver function abnormalities, gingival hyperplasia and a fall in hemoglobin (46). Despite these adverse events, patient withdrawal because of side effects remains relatively low with careful therapeutic drug monitoring. Specific to inflammatory bowel disease will be the considerations of: (i) the effect of enteritis and diarrhea on an already slow and unpredictable cyclosporine absorption; (ii) the effect of associated liver disease on cyclosporine metabolism as cyclosporine is primarily eliminated by hepatic metabolism; (iii) and the interaction between cyclosporine, corticosteroids and nonsteroidal anti-inflammatory agents.

Certainly from our present immunological understanding of inflammatory bowel disease, cyclosporine appears to have great potential in our therapeutic armament. Nevertheless, whether lifelong therapy will be required to maintain remission, whether side effects of therapy will be more serious than the disease itself and whether low dose cyclosporine will be effective and improve patient tolerance can only be confirmed by placebo controlled double blind clinical trials. We await, with some excitement, the results of two separate multicentre double blind Canadian studies examining the role of cyclosporine in active refractory Crohn's disease and in maintaining Crohn's disease remission.

Gastroenterology 1978;75:632-7.

10. Beeken WL. Transmissible agents in inflammatory bowel disease. Med Clin N Am 1980;64:1021-35.

11. Gitnick GL, Rosen VJ, Arthur MH, Hertweck SA. Evidence for the isolation of a new virus from ulcerative colitis patients. Comparison with virus derived from Crohn's disease. Dig Dis Sci 1979;24:609-19.

12. Burnham WR, Lennard-Jones JE, Stanford JL, Bird RG. Mycobacteria as a possible cause of inflammatory bowel disease. Lancet 1978;ii:693-6.

13. Das KM, Valenzuela I, Morecki R. Crohn disease lymph node homogenates produce murine lymphoma in athymic mice. Proc Natl Acad Sci (USA) 1980;77:588-92.

14. Thayer WR, Coutu JA, Chiodini RJ, Van Kruiningen HJ, Merkal RS. The possible role of mycobacteria in inflammatory bowel disease. II. Mycobacterial antibodies in Crohn's disease. Dig Dis Sci 1984;29:1080-5.

15. McLarin L, Gitnick G. Ulcerative colitis and Crohn's disease tissue cytotoxins. Gastroenterology 1982;82:1381-8.

16. Broberger O, Perlmann P. Autoantibodies in human ulcerative colitis. J Exp Med 1959;110:657-74.

17. Strober W, Richman LK, Elson CO. The regulation of gastrointestinal immune responses. Immunol Today 1981;2:156-62.

18. Richman LK, Chiller JM, Brown WR, Hanson DG, Vaz NM. Enterically induced immunologic tolerance. I. Induction of suppressor T lymphocytes by intragastric administration of soluble proteins. J Immunol 1978;121:2429-34.

19. Challacombe S], Tomasi TB. Systemic tolerance and 
secretory immunity after oral immunization. J Exp Med 1980;152:1459-72.

20. Kiyono H, McGhee JR, Wannamuehler MJ, Michalek SM. Lack of oral tolerance in $\mathrm{C} 3 \mathrm{H} / \mathrm{H} 3 \mathrm{~J}$ mice. J Exp Med 1982;155:605-10.

21. Gautam SC, Battisto JR. Orally induced tolerance generates an efferently acting suppressor $\mathrm{T}$ cell and an acceptor $\mathrm{T}$ cell that together downregulate contact sensitivity. J Immunol 1985; 135:2975-83.

22. Schmitz-Moormann P, Becker H. Histologic studies on the formal pathogenesis of the epithelial cell granuloma in Crohn's disease. In:Pena AS, Weterman IT, Booth CC. Strober W, eds. Recent Advances in Crohn's Disease. The Hague: Martinus Nijhoff, 1981:76-93.

23. Strober W, James SP. The immunologic basis of inflammatory bowel disease. J Clin Immunol 1986;6:415-32.

24. Meijer CJLM, Bosman FT, Lindeman J. Evidence for predominant involvement of the B-cell system in the inflammatory process in Crohn's disease. Scand J Gastroenterol 1979;14:21-32.

25. Baklian K, Brandtzaeg P. Comparative mapping of the local distribution of immunoglobulin-containing cells in ulcerative colitis and Crohn's disease of the colon. Clin Exp Immunol 1975;22:197-209.

26. Meuwissen SGM, Feltkamp-Vroom TM, Brutel de la Riviere A, Von Dem Borne AEG, Tytgat GN. Analysis of the lympho-plasmacytic infiltrate in Crohn's disease with special reference to identification of lymphocyte subpopulations. Gut 1976;17:770-80.

27. Strickland RG, Husby G, Black WC, Williams RC Jr. Peripheral blood and intestinal lymphocyte sub-populations in Crohn's disease. Gut 1975; 16:847-53.

28. Selby WS, Janossy G, Bofill M, Jewell DP. Intestinal lymphocyte subpopulations in inflammatory bowel disease: an analysis by immunohistological and cell isolation techniques. Gut 1984:25:32-40.

29. Yardley JH, Donowitz M. Colorectal biopsy in inflammatory bowel disease. In: Yardley JH, Morson BC, Abell MR, eds. The Gastrointestinal Tract. Baltimore: Williams and Wilkins, 1977:50-94.

30. Saverymuttu SH, Peters AM, Lavender JP, Pepys MB, Hodgson HJF, Chadwick VS. Quantitative fecal indium 11 -labelled leukocyte excretion in the assessment of disease in Crohn's disease. Gastroenterology 1983;85:1333-9.

31. Auer IO, Roder A, Wensinek F, van de Merwe JP, Schmidt H. Selected bacterial antibodies in Crohn's disease and ulcerative colitis. Scand J Gastroenterol 1983;18:217-23.

32. Fiocchi C, Battisto JR, Farmer RG. Studies on isolated gut mucosal lymphocytes in inflammatory bowel disease. Detection of activated $T$ cells and enhanced proliferation to Staphylococcus aureus and lipopolysaccharides. Dig Dis Sci 1981;26:728-36.

33. Bull DM, Ignaczak RR. Enterobacterial common antigeninduced lymphocyte reactivity in inflammatory bowel disease. Gastroenterology 1973;64:43-7.

34. Bartnik W, Swarbrick ET, Williams C. A study of peripheral leukocyte migration in agarose medium in inflam. matory bowel disease. Gut 1974;15:294-300.

35. Malchow H, Ewe K, Brandes JW, et al. European Cooperative Crohn's Disease Study (ECCDS): Results of drug treatment. Gastroenterology 1984;86:249-66.

36. Summers RW, Switz DM, Sessions JT, et al. National cooperative Crohn's disease study: results of drug treatment. Gastroenterology 1979;77:847-69.

37. Ptachcinski RJ, Venkatramanan R, Burckart GJ. Clinical pharmacokinetics of cyclosporine. Clin Pharmacokin 1986;11:107-32.

38. Peltekian KM, Williams CN, MacDonald AS, Roy PD, Czolpinska E. Open trial of cyclosporine in patients with severe active Crohn's disease refractory to conventional therapy. Can J Gastroenterol 1988;2:5-11.

39. Bianchi PA, Mondello M, Quarto di Palo F, Ranzi T. Cyclosporin for Crohn's disease. Lancet 1984;i:1242-3.

40. Allison MC, Pounder RE. Cyclosporin for Crohn's disease. Lancet 1984;i:902-3.

41. Allison MC, Pounder RE. Cyclosporin for Crohn's disease. Aliment Pharmacol 1987;1:39-43.

42. Brynskov J, Binder V, Riis R, et al. Clinical experience with cyclosporine in chronically-active, therapy resistant Crohn's disease. A pilot study. Gastroenterology 1987; 92:1330.

43. Vargas V, Guarner L, Accarinoy A, Sanjose A. Cyclosporine in Crohn's disease. Med Clin (Barcelona) 1985;85:301.

44. Cyclosporine in Crohn's disease: report on an international symposium May 12, 1986, London: Sandoz Internal Document.

45. Present DH, Korelitz BI, Wisch N, et al. Treatment of Crohn's disease with 6-mercaptopurine. N Engl J Med 1980; 302:981-7.

46. Von Graffenried B, Krupp P. Side effects of cyclosporine in renal transplant recipients and in patients with autoimmune disease. Transplant Proc 1986;4:876-83.

\section{Clinical Quiz}

Please note, there may be more answers than asked for in the question.

\section{SMALL INTESTINE}

1. List six causes of vitamin $B_{12}$ deficiency. What are the pathogenic processes induced by each cause?

2. Name four causes of the intestinal psuedo-obstruction syndrome and give the pathogenesis of each.

3. Give four renal and urinary complications of Crohn's disease and the mechanisms of these complications.

(Answers page 30)

\section{ESOPHAGUS}

1. What are six indications for surgery in reflux esophagitis?

2. List four features of the typical motility pattern you may expect to see in a patient with well established achalasia of the stomach.

3. Name six complications of endoscopic sclerotherapy of esophageal varices.

(Answers page 44) 


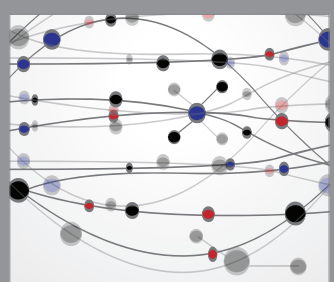

The Scientific World Journal
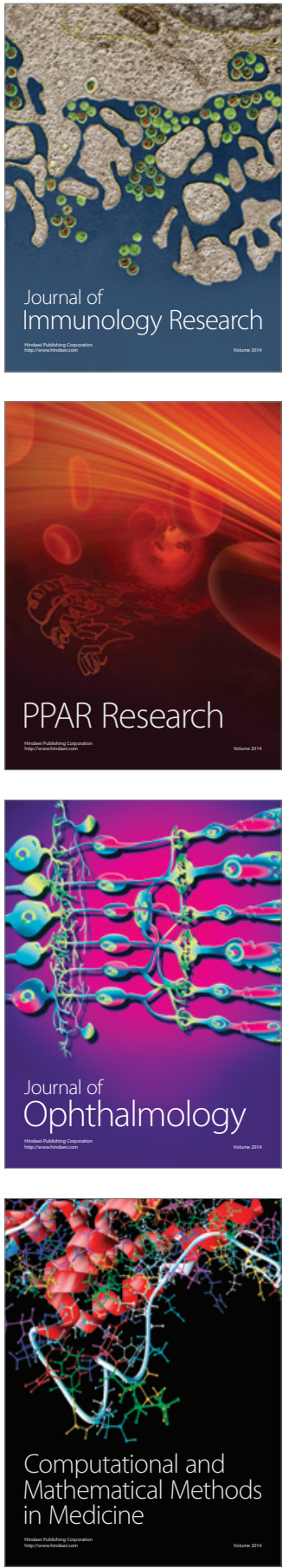

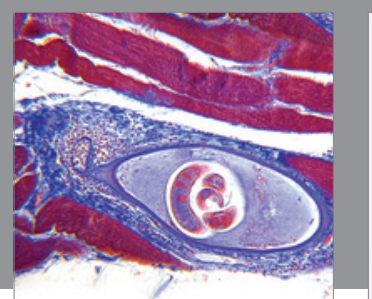

Gastroenterology Research and Practice

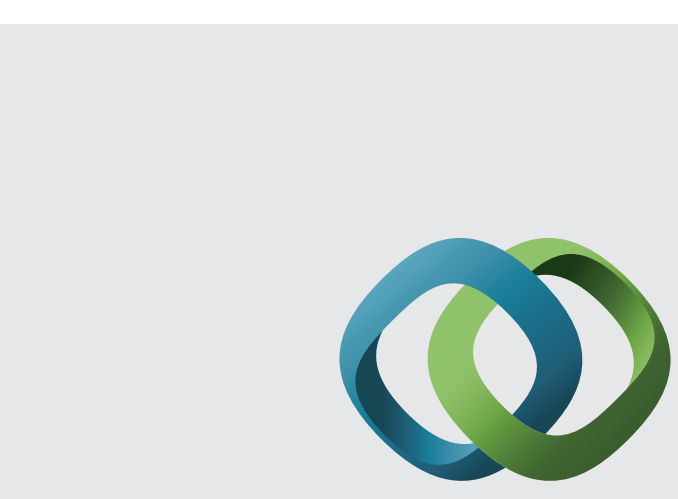

\section{Hindawi}

Submit your manuscripts at

http://www.hindawi.com
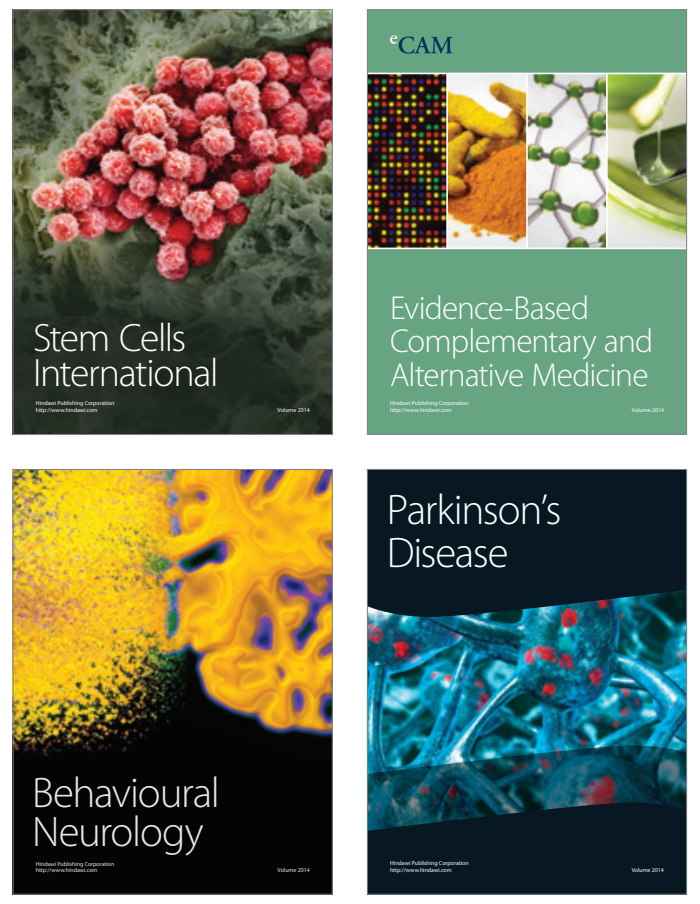
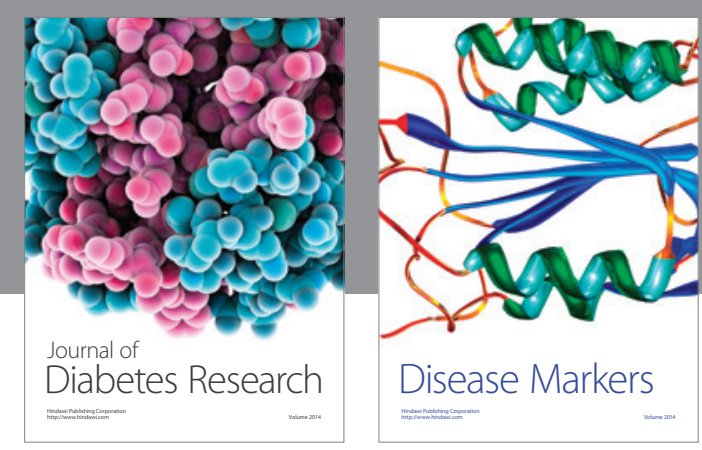

Disease Markers
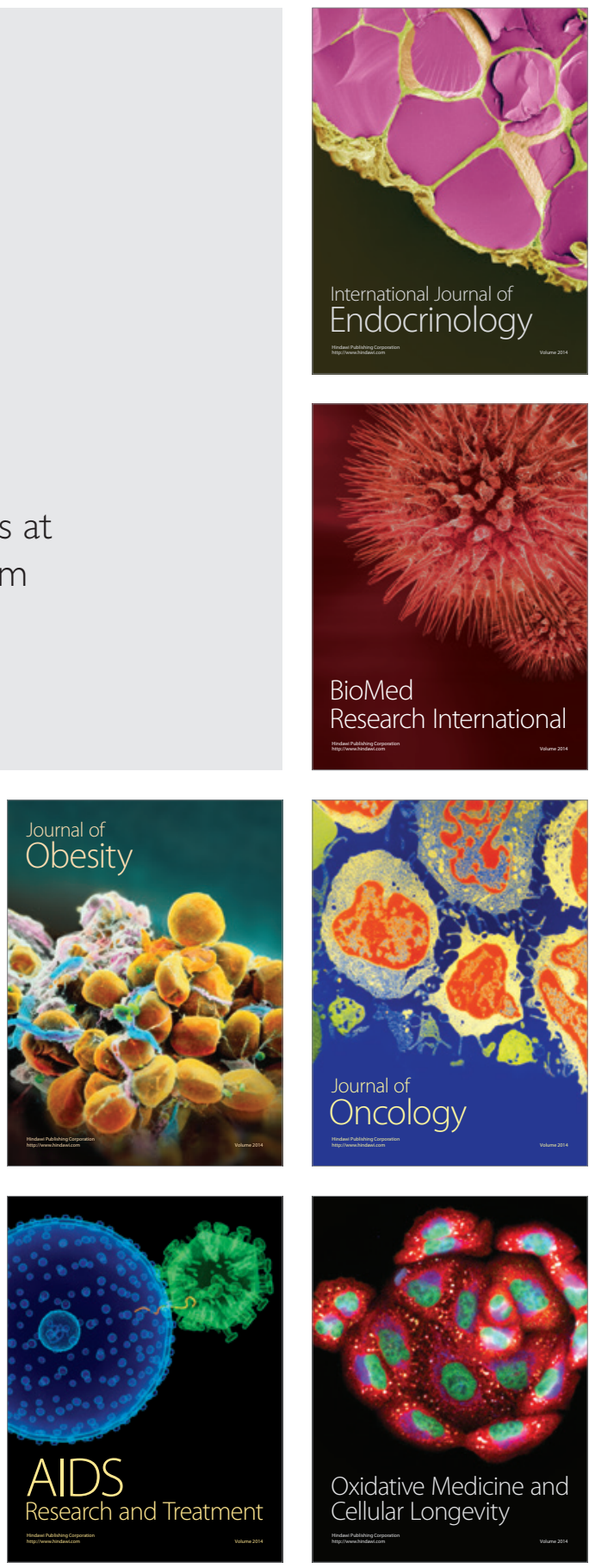